\title{
INTEGRATED PROTECTION MODEL - ISO 45001 AS A FUTURE OF SAFETY AND HEALTH STANDARDS
}

\begin{abstract}
Along with the increase in awareness of the importance of human resources and their contribution to the value of the organization, there is a growing awareness of the need for their management. The fact that modern society prescribes by the law that organizations must identify dangers and hazards, risk level that may arise, as well as their management and implementation of consistent measures to reduce their impact, shows the importance that is attributed to this issue.

For the effective implementation of laws in the field of health and safety at work and other necessary protective measures, there has been a need for a systematic approach to management in this area. Systematic approach to management in the field of health and safety at work ensures the implementation of all measures necessary for the safe operation thus protecting both employees and organization. This systematic approach is reflected in the current standard OHSAS 18001, which aims to establish control over the risks that carry harmful potentials, and thus ensuring the continuity of operation of the organization.

The focus of the scientific community which is actively working on improving the existing standards in the field of safety and health of employees is focused on the upcoming standard that will replace OHSAS 18001. The upcoming standard places a greater emphasis on the risk management and the ongoing assessment of risks and opportunities to prevent or reduce side effects. The innovations in this standard are reflected in the strengthening of the role of top management and top management as well as in the context of the "organization" itself. ISO 45001 provides for active participation of management in all processes of health and safety at work and tends to reduce the usage of process of delegated responsibility to one manager, while, on the other hand, the organization looks at the broader, i.e., the requirements of the wider community are taken into account.
\end{abstract}

Key words: ISO 45001, OHSAS 18001, risk management, top management

Assistant Professor Snežana Živković, PhD, Faculty of Occupational Safety in Niš, e-mail: snezana.zivkvic@znrfak.ni.ac.rs

Dejan Petrović, Master of Safety at Work, Serbian Railways JSC, e-mail: parkerzeleznica@ gmail.com 


\section{Introduction}

Throughout the history of development of the society, work represents one of the most important human needs. Along with the change of human needs, expanding of knowledge, improvement of equipment for work, the nature of work has been changing as well. Although the injuries at work accompanied the work process from the very beginning, much later it became obvious that injuries at work were not just accidents, i.e. the inevitability of the working process, but that those situations, events and processes could be controlled in order to avoid various accidents (occupational injuries, damage to the property and endangering the working environment and so on). Since then, through various initiatives and organizations, the various theories of management of work processes have been created which then have been used as a source of formation of social agreements, non-binding and binding international directives, guidelines and conventions. The process of globalization of the modern era has contributed to implementation of such generally recognized conclusions to be implemented in national legislation and to put safety at work aside as a study subject of a new multi- disciplinary science. Intense international activities of the scientific community on improvement of working conditions lead to gradual standardizing of safe working conditions, access to the organization of occupational safety and measuring the effects of these processes.

\section{Safety at work}

Safety at work is the subject of many sciences, and very often this area is put in the outstanding social context when defining it, i.e. its different aspects are claimed: legal, economic, organizational, psychophysiological, technical, sociological, medical, etc. From that point of view the definition of safety at work, which includes three basic components in it, has arisen:

1) "Occupational safety represents those activities, measures and means that are aimed at achieving safe working conditions.

2) Safe working conditions can be achieved only by using modern technical, social, health, and repression, economic, educational, and organizational and other measures that affect the creation of a safe working environment.

3) All measures must have a preventive character and be directed to the prevention and elimination of the causes of injuries and damage to the workers".

Živković Snežana (2007): Motivacija za zaštitu na radu, Fakultet zaštite na radu u Nišu, Niš. 
Further elaboration and explanation of the concept of safety at work were presented in the Law on Safety and Health at Work ${ }^{2}$. By the adoption of this law, the concept "occupational safety" is transformed into the concept of "safety and health at work", this was later implemented through all bylaws. Pursuant to the provisions of this law, health and safety at work is defined as the provision of such working conditions which, to the greatest extent possible, reduce injuries, occupational diseases and diseases related to work and which mainly create conditions for full physical, mental and social well- being of the employees.

From the above said it can be concluded that there is no single definition of the concept "health and safety at work" and that, depending on the context it refers to, it may conveniently be defined. Particular definition depending on the topic explored contributes specifying the target topic and inappropriate interpretation is being reduces to a minimum.

\subsection{Development of health and safety at work}

There are some very early records of deliberations and considerations of questions of safety at work and recorded accidents at work, but it can be said that the first real researches and defined rules for safe and healthy work were present not earlier than the 19th century, at the time of the peak of industrialization. The first rules in the field of safety and health at work occurred in work areas where conditions were the worst, such as mining, chimney sweeping works, textile, etc. One such example was recorded in 1788 in England, where the law on prohibition of children employment for chimney sweeping operations with respect to all present dangers and hazards in these tasks was passed. ${ }^{3}$

As social movements became more powerful (including trade unions), the social nature of health and safety at work become stronger on the other hand. In other words, in addition to economic the humanitarian nature of health and safety at work was emphasized. While economic character stemmed from the calculated losses because of the absence due to injuries, occupational diseases and diseases related to work, the humanity of work process came to the focus of interests only as a part of strong social reforms based on empowerment of social rights and as an immediate opposite side it had different associations of employers.

Such an interaction of social forces is particularly actual and institutionalized today through social and economic councils and similar bodies.

All this contributed to the fact that the safety and health at work have become one of the criteria of order and progress of society - where safety and

Law on Safety and Health at Work, Official Gazette of the Republic of Serbia, 101/2005.

Nikolić N. et. al. (1977): Osnovi organizacije i zaštita na radu, Institut za dokumentaciju zaštite na radu, Niš.

Vol. 12, No 3, 2015: 165-182 
health at work are more strongly integrated into the social processes, one can expect a better quality of life. Today, health and safety at work is one of the basic human rights enshrined in all basic international documents and national legislation, and it is studied in a large number of higher education institutions.

\subsection{Legal regulation of health and safety at work}

In the context of the legal regulation of health and safety at work, we can talk about international and national regulations.

Basic documents of the International Labor Organization (ILO) and the European Union that regulate the field of health and safety at work are made of the following conventions and directives: Convention no. 155 on occupational safety and health and the working environment (in our country ratified in 1987), the Convention no. 161 on Occupational Health Services (ratified in 1989), the Convention no. 81 on inspection in industry and commerce (ratified in 1956), the Convention no. 135 on workers' representatives (ratified in 1981), as well as the general directive no. 391/89 EEC on the introduction of measures to encourage improvements in the safety and health at work. ${ }^{4}$ The whole system of technical standards established by the International Organization for Standardization, and directives, guidelines and standards of the European Union should be also added.

The basis of safety and health at work in the Republic of Serbia are given in the Constitution of the Republic of Serbia ${ }^{5}$, and more closely defined and edited by the following laws: the Law on Labor, Law on Safety and Health at Work, the Law on Fire Protection, the Law on emergency situations. The enumerated laws are accompanied by numerous bylaws and technical regulations and standards. The common feature to all laws is the obligation of the employer to provide safe working conditions and that this obligation cannot be transferred to somebody else.

\section{Interaction of occupational safety and environment}

\subsection{Systemic dependence of health and safety at work and environmental protection}

Through careful reading of the legal definition that workplace is the "space intended for performing with the employer (indoors or outdoors, as well as on temporary or mobile construction sites, facilities, equipment,

Ivanjac Miroslava, Luković Slavoljub, Mišljenović Dragica (2006): Bezbednost i zdravlje na radu - sindikalni priručnik, UGS Nezavisnost, Beograd.

5 The Constitution of the Republic of Serbia, Official Gazette of the Republic of Serbia, 98/2006. 
means of transport, etc.) in which the employee resides or has access to the course work and which is under direct or indirect control of the employer", and that the "working environment is the space in which the work is performed and which includes working places, working conditions, working procedures and relationships in the work process", common components of working environment, where the environment is the "set of natural and created values which complex interrelationships make the environment, the area and the living conditions".

In the modern definition of process management, health and safety at work and environmental protection cannot be regarded as independent parallel processes that take place within an organization, but as mutually dependent activities. As an example of this connection the presence of material waste in the process of work during the technological process procedure first and then working environment may be mentioned. The discharge of waste material can be controlled and uncontrolled, both in the work and in the living $i$ environment, and both environments can have a mutual negative influence. The same would be true for example of waste energy from the process. ${ }^{8}$

The model of integrated management system - ISO 9001, ISO 14001 and OHSAS 18001, which is very common in modern organizations, displays the practical confirmation of interdependency. In fact, common processes, as well as the benefit based on joint management of these processes have been recognized. ${ }^{9}$

\subsection{An integrated system of management and health and safety at work}

As already mentioned, the most common form of integration management system is based on three standards: ISO 9001, ISO 14001 and OHSAS 18001. ISO 9001 is a system of quality management, ISO 14001 specifies requirements for environmental management, while OHSAS 18001 is a standard that defines management system requirements, safety and health at work.

The aim of OHSAS 18001 standard is to establish control over the risks, i.e. all known risks and hazards, and therefore ensure the smooth operation of the organization. The standard has been developed based on the ISO 14001 standard and is very suitable for smooth integration with ISO 9001 and ISO 14001.

$6 \quad$ Law on Safety and Health at Work, Official Gazette of the Republic of Serbia, 101/2005.

7 Law on Environmental Protection, Official Gazette of the Republic of Serbia 135/2004, 36/2009, 36/2009 - other law 72/2009 - other law and 43/2011 - Decision of the Constitutional court.

8 Anđelković Branislav, Krstić Ivan (2002): Tehnološki procesi i životna sredina, Jugoslovenski savez društava inženjera i tehničara zaštite, Niš.

9 Ristić Goran (2011): "Zaštita na radu u integrisanom sistemu menadžmenta", Zbornik radova Zaštita na radu u 21. veku - teorija i praksa, Fakultet tehničkih nauka, Departman za inženjerstvo zaštite životne sredine i zaštite na radu, Novi Sad. 
As well as ISO 14001, it is based on the PDCA (Eng. Plan- Do-Check-Act) analysis popularized by Edward Deming. ${ }^{10}$ Model OHSAS 18001 of management system for safety and health at work includes the following:

- Policy of safety and health at work;

- Planning;

- The implementation and application;

- Checking and corrective actions;

- Management review. ${ }^{11}$

The reasons for the integration are as follows:

- The common elements of management systems over quality, environment and safety and health at work;

- A simplified management system of all processes in the organization;

- Improved utilization of resources;

- Improved operations of the organization as a whole;

- Incorporating the objectives of all standards in a single policy and business strategy;

- Continuous improvement of the organization includes all equally standardized established processes. ${ }^{12}$

In practice, the most common are the following three models of integration (formation) of a single management system:

- The sequential model (this model, maybe the most used in practice, integrates standards in the following order: ISO 9001, ISO 14001 and OHSAS 18001, and later the relevant standards pursuant to specificities of organization - ISO 22000 for food safety ISO / IEC 27001: 2013 for information safety, etc.);

- The parallel model (simultaneous establishment of all three standards);

- The combined model (in this model, ISO 9001 makes already integrated basis on which ISO 14001 and OHSAS 18001 are simultaneously added, as well as the relevant standards according to the specificities of the organization).13

$10 \quad$ Uzunović Ratko (2001): Menadžment kvalitetom $i$ životnom sredinom, Jugoslovensko društvo za standardizaciju i kvalitet - JUSK, Beograd.

11 BS OHSAS 18001:2008 Management systems of health and safety-Requirements.

12 Ristić Goran (2011): “Zaštita na radu u integrisanom sistemu menadžmenta”, Zbornik radova Zaštita na radu u 21. veku - teorija i praksa, Fakultet tehničkih nauka, Departman za inženjerstvo zaštite životne sredine i zaštite na radu, Novi Sad.

13 Krstić Ivan, Stojiljković Evica, Kusalo Ana, Stojiljković Predrag (2011): "Integrisani sistem zaštite kao osnov analize rizika tehnoloških sistema", Zbornik radova Zaštita na radu u 21. veku - teorija i praksa, Fakultet tehničkih nauka, Departman za inženjerstvo zaštite životne sredine i zaštite na radu, Novi Sad. 
On the other hand, this approach may have adverse effects that are reflected in the following:

- High level of engagement;

- Long-term process;

- The various requirements of stakeholders;

- Lack of motivation;

- Lack of time;

- The uncertainty in the value of an integrated management system;

- High costs of certification;

- Duplication of effort between the external and internal audits. ${ }^{14}$

For the process of integration itself publicly available publication PAS 99: 2012 - Specification of common requirements for the management system as a framework for the integration issued by the British Standards Institute is very useful. This publication has been intended to be a guide for integrated introduction of two or more management systems standards. It brings together the common requirements in standards such as ISO 9001, ISO 14001, ISO / IEC 27001, ISO 22000, ISO / IEC 20000 and / or OHSAS 18001 and establishes the processes of integration.

According to official data, in the Republic of Serbia in 2009 and 2010, the largest number of organizations established two management systems, and then the organizations with 3,4 and 5 of the management systems come. Percentage increase in other management system are: HACCP (77.61\%), ISO 14001 (61.14\%), ISO 18001 (37.03\%), ISO 22000 (4.00\%).

\section{Examples of organizational management structure of health and safety at work in the Republic of Serbia}

\subsection{Safety and Health at Work as a separate process in the organization}

In the Republic of Serbia, pursuant to articles of the Law on Safety and Health at Work, the organization of safety and health at work is entrusted to the employer, i.e., the organization itself decides on the implementation process of health and safety at work taking into account the following:

- Technological process;

- Organization, the nature and extent of the work process;

- Number of employees and the number of working places;

14 Živković Nedeljko (2012): Integrisani sistemi menadžmenta, Fakultet organizacionih nauka, Beograd.

15 Rajković Dragan (2010): Integrisani sistemi menadžmenta u malim i srednjim preduzećima (doktorska disertacija), Mašinski fakultet, Kragujevac. 
- Nature of assessed risks;

- Spatial distribution of working places and allocated work units;

- Type of the activity.

Law on Safety and Health at Work does not define the necessary qualifications of a person for safety and health at work, but only the obligation that the person has passed the examination in accordance with the law. Also, it does not define either the number of required people for health and safety at work, depending on the above factors, but this decision is left to the employer (e.g. an organization with 30 business units across the country, according to the interpretation of the law, can only have one professionally trained person for Safety and Health at Work).

However, if the employer makes such an estimation, for conducting safety and health at work it may engage an external organization that is licensed to perform activities of safety and health at work by the competent ministry or the Agency for Safety and Health at Work.

Selected licensed organization shall appoint one or more persons to perform activities of safety and health at work with a client. Also, activities of work safety and health at work may be performed by the employer alone in the activities of trade, catering and tourism, craft and personal services, financial, technical and business services, education, science and information, health and social care in residential and public utilities, if has up to ten employees and is not required to have passed the certification exam. Thus, by the Law an employer has three defined options for organizing safety and health at work:

- Self-handling activities and health at work;

- The person or persons for Safety and Health at Work with professional exam who are from among the employees;

- The engagement of an external licensed organization.

Of course, the employer can always combine the offered models of organization, and the options include involvement of occupational medicine with an aim to protect the health of employees. It is important to emphasize that the legislation process of health and safety at work separately from other relevant areas leaves the employer possibility to assess the necessity of implementing measures for fire protection, environmental protection, emergency response and related processes in the area of health and safety at work . With respect to this, the following models can be distinguished:

- A centralized management model;

- Department for Safety and Health at Work;

- A decentralized management model. 
A centralized management model implies the appointment of a person for health and safety at work (he/she could be from an external organization) and entrusting the further organization of the activities of safety and health at work to this person. The quality and efficiency of the process of health and safety at work largely depends on the individual characteristics of the appointed person for Safety and Health at Work.

Department for Safety and Health at Work represents, in terms of organization, is also a centralized management system, with the sole difference that within a micro-organization distribution of activities and work duties have been made. Department for Safety and Health at Work usually performs the tasks of fire protection and emergency response. The system, to a lesser extent, still relies on the individual characteristics of the person for Safety and Health at Work.

A decentralized management model implies the acceptance and implementation of standardized processes through OHSAS 18001 standard, its further development, but also development of its own model of safety and health at work management with respect to the basic principles of OHSAS 18001. The analysis of such a model can be made on the basis of the publication of the US Occupational Safety and Health Agency relating to the management of safety and health at work in the Agency itself. A simplified view of three basic elements of the model safety and health at work management is given in Figure 1.

Figure 1: Basic elements of the model of safety and health at work management (own source)

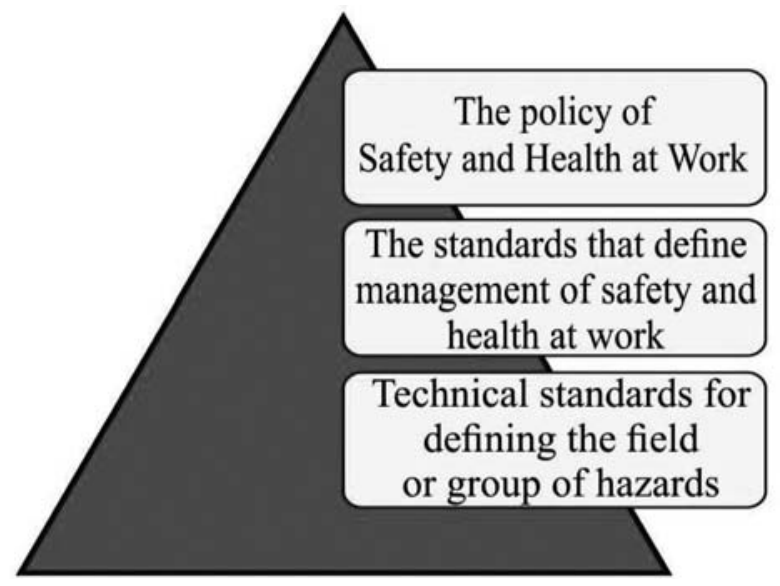

The policy of Safety and Health at Work defines the basic goals and principles of the organization which it strives to, and which will be applied in everyday functioning. The standards that define the way of managing safety and health at work should depict better the real needs and the nature of 
the work process in the organization and thus in the most peculiar way define the core management processes, and in particular the following ones:

- Participation of the management;

- The method of promotion and motivation for safe and healthy work;

- The process of risk assessment in the workplace and working environment;

- Health management at work - participation of occupational medicine;

- Incidents management;

- Definition of preventive and corrective measures;

- Managing the third parties (contractors, stakeholders, etc.);

- Managing changes in an organization.

Technical standards for defined areas, i.e., groups of hazards, represent some sort of plan for preventive security measures for safe and healthy work. This group of technical standards can be very different depending on the activities of that organization, but it will certainly include the following elements, i.e., defined measures for safe and healthy work:

- Work equipment (machines, devices, equipment, tools, aids, etc.).

- Electricity and lightning;

- Fire Protection;

- Emergency management;

- Equipment for screen operation;

- Work in the office;

- Industrial hygiene (physical, chemical and biological hazards);

- Pedestrian and work surfaces;

- Providing first aid.

Additional elements, depending on the activities of the organization, can be:

- Work at height;

- Work in a limited (confined) space;

- Noise in the workplace;

- The internal transport;

- Ionizing radiation;

- Hazardous substances;

- The loading and unloading of cargo.

The system functions in that way that a standard of management is applied to each technical standard. With such a default organization, there is a distribution of duties, i.e., employees from different hierarchical positions and qualifications receive adequate training, authorization and obligation to implement a certain standard throughout the organization. In this way, a larger number of employees shall be included in the definition of preventive measures, thus 
increasing the awareness of the importance of health and safety at work at the level of the whole organization. The so-called "The owners of the standards" are typically chosen based on qualifications and their previous experience. E.g. "The owner of the standard" for participation of management may be a director, management of third parties can be done by the authorized person from the Human Resource or by the project manager if they engage contractors; the same key can be applied to technical standards - "the owner of standards" for electricity can be the head of maintenance department, for organizing first aid it can be a person who has already had an education in that field and so on. In this system, the function of the person of the safety and health at work turns into a control (managerial) position that provides the following components:

- Setting the systems of safety and health at work;

- $\quad$ Setting the applicable standards;

- Selection of people of the future "the owners of the standards";

- Training and other professional assistance;

- Monitoring system;

- Measures for continuous improvement.

In accordance with a defined structure, the "owners" themselves and sectors cooperate interactively in the field of health and safety at work, and therefore some employees are being encouraged and authorized as leaders of some of the processes thus increasing the motivation for the implementation of the process, in this case, safety and health at work. As motivation in this process is present, the motives of pleasure and benefits are present, too. ${ }^{16}$

\subsection{An integrated model of health and safety at work and environmental protection}

The connection of working and living environment, both in their conceptual definition and the management of the integration process has been earlier pointed to. Also, it has been stated that the identification and integration process of the environment in the process of health and safety at work depend on the assessment of the employer or organization. In respect to this, following options of relation of health and safety at work and environmental protection can be differentiated:

- Special, independent flows;

- The centralized model in two forms:

- Person for Safety and Health at Work and the Environment Protection (OHS manager or EP MANAGER);

- Service for Safety and Health at Work and the Environment (Department of OHS and EP);

- Decentralized system.

16 Živković Snežana (2007): Motivacija za zaštitu na radu, Fakultet zaštite na radu u Nišu, Niš. 
The special, independent flows imply that the organization has a manager to manage the processes of health and safety at work and a manager to manage the processes of environmental protection.

Centralized management model involves the appointment of a person responsible for health and safety at work and environmental protection (this person may be from external organizations) and entrusting further organization of safety and health at work and environmental protection to that person. Department for Safety and Health at Work and the Environment represents, in terms of organization, also a centralized management model with the difference that within a micro-organization distribution of work duties has been made. The department usually performs the tasks of fire protection and emergency response.

A decentralized management model implies the acceptance and implementation of standardized processes through standard OHSAS 18001 and ISO 14001, and its further development, but also development of its own model of management the safety and health at work and environmental protection according to the basic principles of OHSAS 18001 and ISO 14001. As an illustration of such a system, the already presented an example of decentralized management safety and health at work can be upgraded (Figure 2).

Figure 2: Basic elements of the management model of safety and health at work and environmental protection (own source)

\section{Safety and health at work and Environmental protection policies}

\section{Management standards}

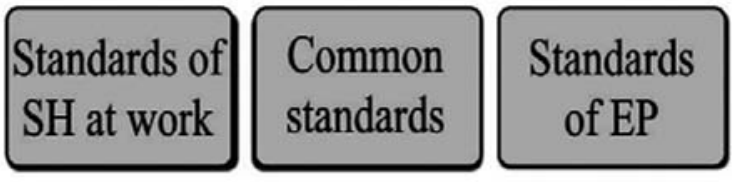

Integration of ISO 14001, i.e., environmental protection, leads to the following organizational changes:

- The EP policy joins the OHS policy thus forming a unique OHS and EP Policy; 
- Control standards are expanding their range of application to the environmental protection as well, and new categories (objectives, monitoring, definitions of incidents and accidents, etc.) are being introduced;

- Technical standards are divided into three groups and a new appointment, "the owner of standards" are being made.

Grouping of standards common for safety and health at work and environmental protection depends on the activities of the organization, and examples of these common elements are:

- Industrial hygiene (physical, chemical and biological hazards);

- Noise;

- Hazardous substances;

- Ionizing Radiation.

Grouping of environmental standards, depending on the activity of organization and pursuant to the existing Law on Environmental Protection, can be made of the following standards:

- Air quality;

- The quality of water;

- The soil quality;

- Management of hazardous and non-hazardous waste;

- Management of chemicals.

This decentralized system promotes the responsible people for Safety and Health at Work and the people responsible for environmental protection into the control (management) function. The system leaves the option that the organization has a manager for Safety and Health at Work and a manager for environmental protection or that both processes are managed by one manager.

\section{Emerging standard - ISO 45001}

In October 2013 International Organization for Standardization established a committee ISO / PC 283, to create a new standard for the management of safety and health at work, ISO 45001, which will replace the existing OHSAS 18001. The adoption of the new standard is expected in the second half of 2016, and for now only contents of standards is available, and it is the proposal phase. The very structure of the standard will be in accordance with Annex SL directive which governs the development of ISO standards. 


\subsection{News in ISO 45001 standard}

The aim of the standard remains the same: to set requirements for management systems of protection and safety of employees, and thus to help organizations ensure the health and safety of people who work for them. However, the fact that the standards will follow the structure of ISO 9001:2015 and ISO 14001:2015 indicates that a stronger focus will be on the context of the organization. The concept of the context requires organizations to look beyond health and safety within their own facilities and to take into account the working conditions in the supply chain. Other change that can be expected is a stronger role for top management. Health and safety will become central aspects of the overall management system, which requires a firm commitment of top management. The integration of management systems of protection and safety of employees in general management system will be facilitated by the fact that ISO 45001 adopts the same structure as ISO 9001 and ISO 14001.

\subsection{Why ISO 45001 ?}

Analyzing the devastating statistics on the number of accidents related to health and safety at work, according to which 2.2 million workers globally lose their lives each year due to occupational accidents and diseases related to work, while in the US over 4.1 million workers suffer serious illness or injury each year ${ }^{17}$, where in the UK 26.4 million working days are lost due to illness related to labor and occupational injuries ${ }^{18}$, the loss of $4 \%$ of the world's gross domestic product due to occupational injuries and diseases ${ }^{19}$, where 6,300 workers die every day due to the consequences of occupational injuries and illnesses related to work ${ }^{20}$, there is an urgent need for organizations around the world to improve their management systems of protection and safety of employees - and this need will only grow in the future. By further globalization, more and more consumers and customers expect that organizations put greater emphasis on ethics in every aspect of its operations, including the way they treat their employees.

By the implementation of future international standards, small, medium and large organizations in any field of business can set a benchmark for their safety and health management, policy and practice in different geographical areas, countries, cultures and jurisdictions. This will promote better communi-

\footnotetext{
$17 \quad$ FY 2013 Annual performance report, (2013): US Department of Labor Report.

18 Health and Safety Executive Annual Statistics Report (2011): Health and Safety Executive, UK.

19 Global and Asian trends for Safety and Health at Work 2006 (2007): Department of Public Health and Environment, World Health Organization.

20 International Labor Organization (2013): Statistics, http://www.ilo.org (2. 4. 2015).
} 
cation on common issues, principles and best practices in global trade. This standard will allow companies to comply with regulatory requirements, including responsibilities, specifications and ethical corporate governance and auditing practices.

After the implementation of a standardized framework, companies can align their operations with national and international legislation and codes of conduct - improving risk management and planning for emergencies. ISO 45001 will also allow organizations to set up and evaluate measures for service providers. As a result, companies will be able to reduce the number of accidents in relation to health and safety at work and related costs, at the same time promoting the welfare of its employees and its environment.

\section{Conclusion}

Safety and health at work has come a long historical way from the process of the very recognition of the importance of health and safety at work to formation of different models of managing safety and health at work. Models of managing safety and health at work ranges from strictly centralized to decentralized basis in the model. Comparing the basic processes of recognized management models and taking into account the definition of the concept of "health and safety at work" far greater advantage of decentralized management systems can be emphasized. The reason lie in the fact that the mere setting of such a system promotes a large number of leaders in certain systems and processes at different hierarchical levels of organization (from top management to employees in the "front line"). Thus organization publicly demonstrates confidence in its employees, encouraging them to continue professional development, but also strengthens the motivation for the implementation of safety and health at work, and therefore the application of preventive measures for safe and healthy work at the workplace and working environment.

Taking into account the fact that the commitment of employees is one of the main aspects of the upcoming international standard for the management of safety and health at work, thus decentralized management system receives an international recognition, created the conditions for such management models to enter our legislation as an obligation for all organizations. It is expected that the introduction of the new standards will contribute to greater participation of top management in the health and safety at work, and therefore the greater participation of employees, both in the application of the prescribed measures for safe and healthy work, as well as active contribution to defining these measures.

Future standard for managing safety and health at work will support the new management systems to ensure better compatibility and system manage- 
ment, which will make the application within the organization much easier. ISO 45001 will also have a direct impact on society. With more established international system of protection of health and safety at work, the number of incidents and accidents will be reduced with the least possible disruption of operational processes. This means a smaller number of urgently needed treatments in the workplace and in hospitals and reduced long-term care for those who are unable to return to work after the accident. ISO 45001 will undoubtedly mark the beginning of the global changes in the field of health and safety at work.

\section{Literature}

- Anđelković Branislav, Krstić Ivan (2002): Tehnološki procesi i životna sredina, Jugoslovenski savez društava inženjera i tehničara zaštite, Niš

- BS OHSAS 18001:2008 Management systems of health and safety Requirements. (2008)

- FY 2013 Annual performance report, US Department of Labor Report, 2013

- Global and Asian trends for Safety and Health at Work 2006, Department of Public Health and Environment, World Health Organization, 2007

- Health and Safety Executive Annual Statistics Report, Health and Safety Executive, UK, 2011

- Ivanjac Miroslava, Luković Slavoljub, Mišljenović Dragica (2006): Bezbednost i zdravlje na radu - sindikalni priručnik, UGS Nezavisnost, Beograd

- Krstić Ivan, Stojiljković Evica, Kusalo Ana, Stojiljković Predrag (2011): "Integrisani sistem zaštite kao osnov analize rizika tehnoloških sistema”, Zbornik radova Zaštita na radu u 21. veku - teorija i praksa, Fakultet tehničkih nauka, Departman za inženjerstvo zaštite životne sredine i zaštite na radu, Novi Sad, 111-116

- Law on Safety and Health at Work, Official Gazette of the Republic of Serbia, 101/2005

- Law on Environmental Protection, Official Gazette of the Republic of Serbia 135/2004, 36/2009, 36/2009 - other law 72/2009 - other law and 43/2011 - Decision of the Constitutional court

- Nikolić, N. et. al. (1977): Osnovi organizacije i zaštita na radu, Institut za dokumentaciju zaštite na radu, Niš

- Rajković Dragan (2010): Integrisani sistemi menadžmenta u malim i srednjim preduzećima (doktorska disertacija), Mašinski fakultet, Kragujevac

- Ristić Goran (2011): "Zaštita na radu u integrisanom sistemu menadžmenta”, Zbornik radova Zaštita na radu u 21. veku - teorija $i$ 
praksa, Fakultet tehničkih nauka, Departman za inženjerstvo zaštite životne sredine i zaštite na radu, Novi Sad, 56-61

- Statistics, International Labour Organization, 2013, http://www.ilo.org (2. 4. 2015)

- The Constitution of the Republic of Serbia, Official Gazette of the Republic of Serbia, 98/2006

- Uzunović Ratko (2001): Menadžment kvalitetom $i$ životnom sredinom, Jugoslovensko društvo za standardizaciju i kvalitet - JUSK, Beograd

- Živković Snežana (2007): Motivacija za zaštitu na radu, Fakultet zaštite na radu u Nišu, Niš

- Živković Nedeljko (2012): Integrisani sistemi menadžmenta, Fakultet organizacionih nauka, Beograd 


\author{
Prof. dr Snežana Živković \\ Fakultet zaštite na radu u Nišu \\ Mr Dejan Petrović \\ JP Železnice Srbije
}

\title{
INTEGRISANI MODEL ZAŠTITE - ISO 45001 KAO BUDUĆNOST STANDARDA BEZBEDNOSTI I ZAŠTITE ZDRAVLJA
}

\begin{abstract}
S a ž e t a k
Uporedo sa porastom svesti o značaju ljudskih resursa i njihovom doprinosu vrednosti organizacije, sve više raste i svest o potrebi njihovog upravljanja. O značaju koji se pridaje ovoj oblasti govori činjenica da savremena društva zakonom propisuju da organizacije moraju utvrditi opasnosti i štetnosti, visinu rizika koji se mogu javiti, moraju upravljati njima i sprovoditi konstantne mere za smanjenje njihovog uticaja.

Za efikasno primenjivanje zakona iz oblasti bezbednosti i zdravlja na radu i drugih neophodnih mera zaštite, pojavila se potreba za sistemskim pristupom upravljanja u ovoj oblasti. Sistemski pristup upravljanja u oblasti bezbednosti i zdravlja na radu obezbeđuje primenu svih neophodnih mera za bezbedan rad, čime se štite i zaposleni i organizacija. Ovakav sistemski pristup ogleda se u aktuelnom standardu OHSAS 18001, koji ima za cilj uspostavljanje kontrole nad rizicima koje nose štetnosti i opasnosti, a samim tim i obezbeđivanje kontinuiteta poslovanja organizacije.

Fokus naučne zajednice koja aktivno radi na usavršavanju postojećih standarda iz oblasti upravljanja bezbednošću i zdravljem zaposlenih usmeren je na najavljeni standard koji će zameniti OHSAS 18001. Budući standard stavlja veći naglasak na upravljanje rizikom i tekuće procene rizika i mogućnosti za sprečavanje ili smanjenje neželjenih efekata. Novine u standardu se ogledaju u jačanju uloge top menadžmenta i najvišeg rukovodstva, kao i u samom kontekstu „organizacije“. ISO 45001 predviđa aktivnije učešće menadžmenta u svim procesima bezbednosti i zdravlja na radu i teži da umanji običaj delegiranja obaveza upravljanja procesima jednom menadžeru, dok se, s druge strane, organizacija posmatra šire, tj. uzimaju se u obzir i zahtevi šire društvene zajednice.
\end{abstract}

Ključne reči: ISO 45001, upravljanje rizikom, top menadžment, OHSAS 18001 